\title{
FLAX RETTING USING SPRINKLER SYSTEM
}

\author{
T. M. Attafy ${ }^{1}$ and A. M. Mousa ${ }^{2}$
}

\begin{abstract}
This study was undertaken to examine sprinkler retting as an eco-friendly method compared with water (traditional) retting. For this purpose an experiment under open field conditions was carried out in fiber crops research department, Gemmiza Research Station, Gharbeiah
\end{abstract} Governorate, middle of the Nile Delta, Egypt during autumn season of 2017. The microsprinkler irrigation system was applied with four levels operating pressure head namely; $5 \mathrm{~m}\left(P_{1}\right), 7.5 \mathrm{~m}\left(P_{2}\right), 10 \mathrm{~m}\left(P_{3}\right)$ and 12.5 $m\left(P_{4}\right)$ and two operating times namely; $1.5 \mathrm{~h} /$ day $\left(T_{1}\right)$ and $3 \mathrm{~h} /$ day $\left(T_{2}\right)$. Main results cleared out that, increasing operating pressure head increased water application uniformity, sprinkler retting decreased total applied water compared with water (traditional) retting, The lowest total applied water was $8.33 \mathrm{~m}^{3} /$ ton straw obtained at $T_{2} P_{4}$ treatment, while The highest one was $13.3 \mathrm{~m}^{3} /$ ton straw obtained at $T_{2} P_{1}$ treatment and total applied water for water retting was $10.45 \mathrm{~m}^{3} /$ ton straw. Traditional/water retting produced highest fiber percentage, 16.4\%; while the highest fiber percentage under sprinkler retting was $15.5 \%$ obtained at $T_{2} P_{4}$ treatment, traditional/water retting produced highest fiber length $(87.5 \mathrm{~cm})$, while $\mathrm{T}_{2} \mathrm{P}_{2}$ treatment produced highest fiber fineness (273). The highest_water productivity was $18.6 \mathrm{~kg} / \mathrm{m}^{3}$ obtained at $T_{2} P_{4}$.

\section{INTRODUCTION}

Dlax fibers have wide application in many industries like, the textile, construction, paper and automotive industries. Flax

1 contains fibers in the cortex region of the stem, these bast fibers are separated from nonfiber tissues by retting, and the fibers are then mechanically cleaned to remove nonfiber. In Egypt water retting is used as follow, the flax straw arranged vertically in bundles then put in retting basin and submerged with water, after $24 \mathrm{~h}$ the water was changed to leach out the soluble materials.

\footnotetext{
${ }^{1}$ Researcher, Agric. Eng. Res. Inst., Agric. Res. Center, Egypt.

${ }^{2}$ Head researcher, field crop Res. Inst., Agric. Res. Center, Egypt.
} 
Retting period lasted for about one week the average temperature of the water was $28-30^{\circ} \mathrm{C}$ and $\mathrm{pH}$ value was $6-7$ when the $\mathrm{pH}$ of the retting water reached about 4.5 and fibers were easily separated from straw the retting process was be finished. The straw was washed with clean water and dried in open air.

Van Sumere (1992) reported that water retting produces better quality fibers, but the stench from fermentation by anaerobic bacteria, the resulting stench-tainted fibers, and high labor costs prevent water retting from being widely used today, So dew retting; which is the oldest procedure has returned as the method of choice in Europe due to the problems. Henriksson et al. (1998) explained a commonly method used in central Europe of separating ligneous parts of stems from fibers, extracting them and removing the non-cellulosic residues is the so-called dew retting where the retting done on the fields. The retting process involves spreading the straw on the ground, where it is subjected to moisture and later to microbial action. Dew retting also suffers from many disadvantages, including large variations in fiber quality, limitation to geographical regions with appropriate temperature and moisture, high labor costs, and occupation of agricultural land for several weeks. Dew retting does not allow farmers to prepare the field for next crop in appropriate time. Therefore, they recommended that considerable efforts must be make to replace the traditional retting methods by other means like chemical retting, steam explosion and enzymatic retting. Evans et al. (2002) resulted that dew-retted fibers can vary from fine (high quality) fibers to coarse (low quality) ones, this variation can negatively affect the final quality of the spun yarn. The variation in quality may be attributed to numerous uncontrollable factors, including moisture (rainfall and dew), temperature and activity of the microbial flora. Kozlowski et al (2006) resulted that extraction of fibers from the plant relies on degumming allows for obtaining fiber characterized by high quality, uniformity and lower linear density comparing with traditional retting methods. Konczewicz and Wojtysiak (2015) resulted that using warm water instead of the cold water in water retting allows for lessening the time under controlled conditions (temperature and $\mathrm{pH}$ ), where the retting continue between 70 and 100 hours, this process can perform both in aerobic and anaerobic conditions. They added that the conventional 
technology of warm water retting required consumption of high amounts of water and produced highly contaminated retting wastes at different stages of the process. Konczewicz et al. (2017) evaluated effect of two different methods of fiber extraction (dew retting and osmotic degumming) on fiber properties. The results proved that, osmotic degumming improved significantly the fiber quality. They concluded that osmotic degumming fibers method is more suitable for composite reinforcement.

Playan et al. (2006) referred to the design and operational factors that affect the performance of sprinkler irrigation; design factors include sprinkler type, use of one or two nozzles, nozzle diameters and sprinkler spacing, while operational factors include working pressure, time of irrigation, environmental conditions during irrigation and mainly wind speed. Sanchez et al. (2010) evaluated Christiansen's uniformity coefficient $(\mathrm{Cu})$ under square layout $(\mathrm{R} 15 \times 15)$ and rectangular layout $(\mathrm{R} 18 \times 15)$, the results indicated that, $\mathrm{Cu}$ value was $5 \%$ greater under square layout than under rectangular layout, and the average of wind drift and evaporation losses under rectangular layout were greater than that under square layout. Mehawed et al. (2013) recommended that under arid ecosystems of Egypt the spatial distribution of sprinklers have to be not less than $67-70 \%$ from diameter of throw for rotating sprinkler and small nozzle impact ones and 50-55\% from diameter of throw for large nozzle impact sprinkler. Zhu et al. (2015) compared hydraulic performance for three types of sprinklers: a signal sprinkler (OS), a fluidic sprinkler (FS), and an impact sprinkler (IS) under indoor experimental conditions. They indicated that at low pressure OS and FS provided a more acceptable water distribution pattern.

The purpose of this research is replacing traditional retting method by sprinklers method as an eco-friendly method to minimize applied water, odor, labor and cost. Evaluating the optimum operating pressure head of sprinklers network to extract high-quality homogeneous fibers.

\section{MATERIALS AND METHODS}

\subsection{Experimental layout}

This study was carried out in Fiber Crops Research Department, Gemmiza Research Station, Gharbeiah Governorate, middle of the Nile Delta, Egypt, during September and October, 2017. Mean climatic data 
for October and November 2017 (temperature and relative humidity) were obtained from Agricultural Research Center, EL-Giza as shown in Table 1.

Table 1: Mean climatic data for October and November 2017.

\begin{tabular}{|c||c|c||c|c||}
\hline \multirow{2}{*}{ Month } & \multicolumn{2}{c||}{ Temperature, $\mathrm{C}^{\circ}$} & \multicolumn{2}{c||}{ Relative humidity, \% } \\
\cline { 2 - 5 } & Max. & Min. & Max. & Min. \\
\hline \hline October & 29.2 & 14.6 & 81.6 & 53.8 \\
\hline November & 25.2 & 13.3 & 88.6 & 55.9 \\
\hline
\end{tabular}

\subsection{Preparation of flax steams}

Flax seeds cultivar Giza 11 were grown during the winter season of 2016/2017 in Gemmiza Research Farm under optimum conditions (seeding density, irrigation, fertilization and plant maturity). Plants were pulled manually on April, dried in open field for several days and seeds were separated mechanically, thereafter flax stems stored inside protected sheds to prevent any retting or weathering by indigenous micro organisms. Before starting retting process directly, flax steams were packed into small bundles weighing $500 \mathrm{~g} /$ bundle; every 30 small bundles were collected in main bundle had $0.7 \mathrm{~m}$ diameter. For every treatment, the main bundle was fixed vertically into the distance between sprinklers. Water retting was accomplished using poly vinyl chloride (PVC) pipes with 8 inch outer diameter and $130 \mathrm{~cm}$ height prepared for this purpose. Flax straw bundles were submerged with water into the pipes, as shown in Fig. 1. Retting process stopped when all the pectic materials were dissolved and the small bundles were removed and dried in sun and air. The woody materials were broken away machinery to form cellulose fibers.

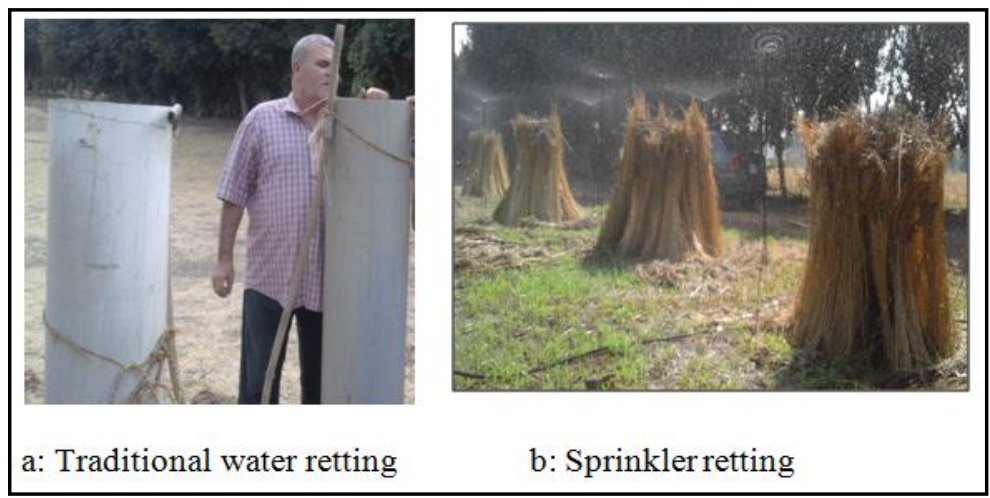

Fig: 1. Sprinkler and traditional retting methods. 


\subsection{Sprinkler irrigation network}

Sprinkler irrigation system under study consisted of centrifugal pump (3 inch inlet and outlet diameters and $30 \mathrm{~m}^{3} / \mathrm{h}$ nominal discharges) driven by $3.75 \mathrm{~kW}$ internal combustion engine, back flow prevention device, pressure gauges, flow-meter, control valves, mainline, sub-main lines, laterals and sprinklers. Main line was Aluminum pipes with $75 \mathrm{~mm}$ outer diameter, sub-main lines were poly vinyl chloride (PVC) pipes with 32 $\mathrm{mm}$ outer diameter which were connected to the main line by $32 \mathrm{~mm}$ control valves and lateral lines were poly ethylene (PE) pipes with $16 \mathrm{~mm}$ outer diameter connected to the sprinkler with $8 \mathrm{~mm}$ outer diameter spaghetti tube and $120 \mathrm{~cm}$ stake height. Sprinkler network was scheduled to work once every day. Hydraulic performance of rotator microsprinkler at overlapping $100 \%$ in terms of (Pressure - discharge - radius of throw relationship) is shown in Fig. 2.

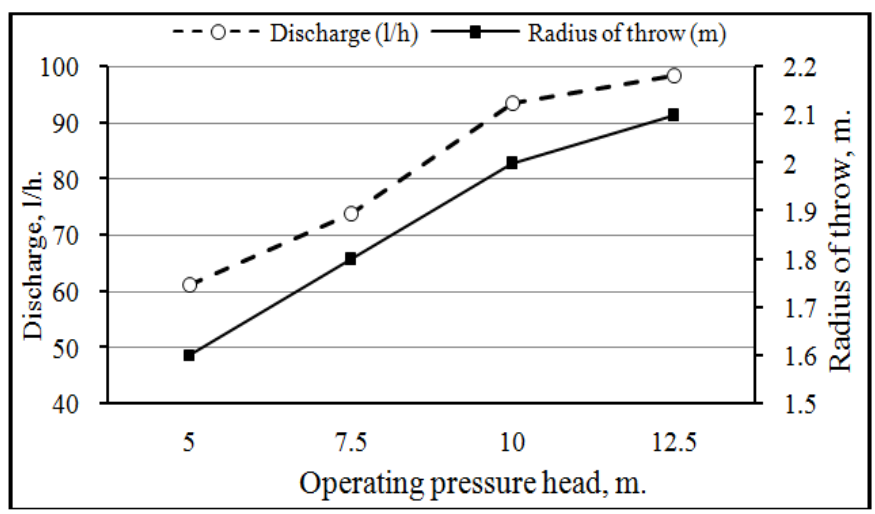

Fig. 2: Effect of operating pressure head on discharge and radius of throw for rotator microsprinkler.

\subsection{Treatments}

Rotating microsprinkler with four operating pressure head namely; $5 \mathrm{~m}$ $\left(\mathrm{P}_{1}\right), 7.5 \mathrm{~m}\left(\mathrm{P}_{2}\right), 10 \mathrm{~m}\left(\mathrm{P}_{3}\right)$ and $12.5 \mathrm{~m}\left(\mathrm{P}_{4}\right)$ and two operating times namely; $1.5 \mathrm{~h} /$ day $\left(\mathrm{T}_{1}\right)$ and $3 \mathrm{~h} /$ day $\left(\mathrm{T}_{2}\right)$ were used to evaluate sprinkler retting and compared it with control treatment water (traditional) retting. The study treatments and experimental field layout and distribution are shown in Fig. 3. 


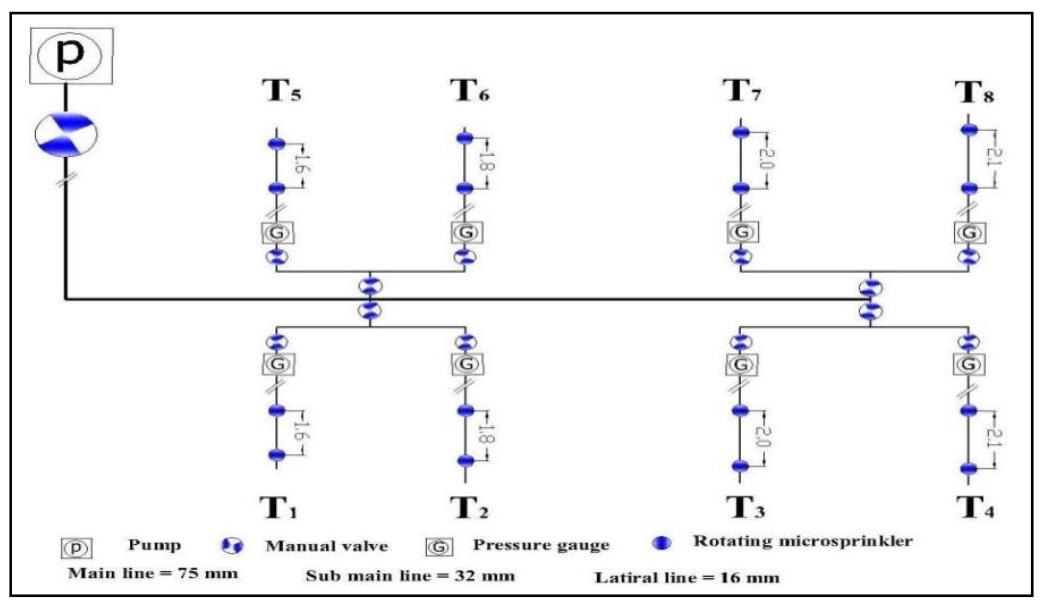

Fig. 3: The experimental field layout and study treatments distribution.

\subsection{Measurements}

\subsubsection{Water application uniformity:}

Effect of operating pressure head under experimental conditions on application uniformity was expressed by Christiansen uniformity coefficient $(\mathrm{Cu})$ and water distribution uniformity $(\mathrm{Du})$ according to (James, 1988).

$$
\mathrm{C}_{\mathrm{u}}=100\left(1.0-\frac{\sum\left|\mathrm{x}_{\mathrm{i}} \mathrm{x}^{-}\right|}{\mathrm{nx}^{-}}\right)
$$

Where:

$\mathrm{x}_{\mathrm{i}}=$ Volume caught at observation point $\mathrm{i}$,

$\mathrm{x}^{-}=$Average volume amount caught, and

$\mathrm{n}=$ Number of observations.

$$
\mathrm{Du}=100 \times \frac{x_{\mathrm{lq}}}{x^{-}}
$$

Where:

$$
\begin{aligned}
& x_{\mathrm{lq}}=\text { Low-quarter average volume amount caught at observation } \\
& \text { points. }
\end{aligned}
$$

\subsubsection{Total applied water:}

The amount of water added to each treatment from the beginning of retting process until completion was calculated, and it was related to ton of flax straw $\left(\mathrm{m}^{3} /\right.$ ton $)$.

\subsubsection{Fiber technological characters:}

a. Total fiber percentage: It was calculated for ton of straw from the following formula: 


$$
\text { Total fiber percentage }=\frac{\text { Fiber yield after retting }}{\text { Straw yield before retting }} \times 100--(3)
$$

b. Fiber fineness: It was calculated according to (Radwan and Momtaz, 1966).

$$
N m=\frac{N . L}{W} \quad-------(4)
$$

Where:

$$
\begin{aligned}
& N m=\text { Metrical number } \\
& N=\text { Number of fibers ( } 20 \text { fibers) and the length for each one }=10 \mathrm{~cm} . \\
& L=\text { Length of fibers in mm. } \\
& W=\text { Weight of fibers in } \mathrm{mg} .
\end{aligned}
$$

c. Fiber length: Ten fiber ribbons from each treatment were separated out and each ribbon was measured then the average fiber length was recorded in $\mathrm{cm}$.

\subsubsection{Water productivity:}

Water productivity $(W P)$ for ton of straw, ( $\mathrm{kg}$ fiber/ $\mathrm{m}^{3}$ water) was calculated as following:

$$
\mathrm{WP}=\frac{\text { Total fiber yield }, \mathrm{kg}}{\text { Total applied water }, \mathrm{m}^{3}}
$$

\section{RESULTS AND DISCUSSION}

\subsubsection{Water application uniformity:}

Effect of operating pressure head under experimental conditions on Christiansen uniformity coefficient $(\mathrm{Cu})$ and water distribution uniformity is shown in Fig. 4. The results indicated that Christiansen uniformity coefficient $(\mathrm{Cu})$ and distribution uniformity $(\mathrm{Du})$ were affected by operating pressure head. Increasing operating pressure head from 5 to $12.5 \mathrm{~m}$ increased $(\mathrm{Cu})$ and $(\mathrm{Du})$. Maximum values for $(\mathrm{Cu})$ and (Du) were $94.9 \%$ and $92.3 \%$, respectively at $12.5 \mathrm{~m}$ operating pressure head, while minimum values were $53.6 \%$ and $49.0 \%$ respectively at $5 \mathrm{~m}$ operating pressure head. These results are in agreement with Hassan et al (2007). It could be recommended that the optimum operating pressure head for rotator microsprinkler were $12.5 \mathrm{~m}$. 


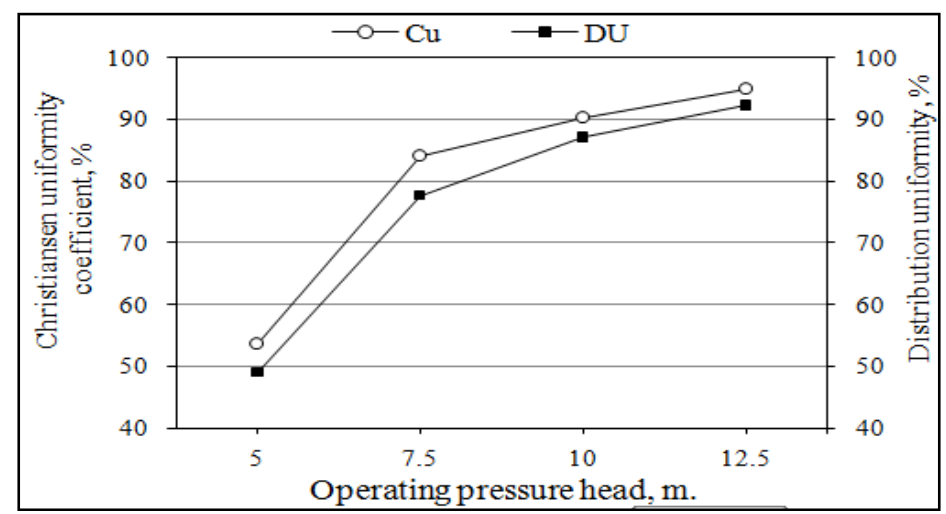

Fig.4. Effect of operating pressure head on Christiansen uniformity coefficient and distribution uniformity.

\subsubsection{Total applied water:}

The Total applied water $\left(\mathrm{m}^{3} /\right.$ ton straw) in relation to retting method, operating time and operating pressure head are shown in Fig 5. The obtained results indicated that, total applied water was affected by retting method, operating time and sprinkler operating pressure head, where sprinkler retting led to less amount of applied water compared with water retting. Under sprinkler retting, increasing operating pressure head from 5 to $12.5 \mathrm{~m}$ decreased total applied water; these results may be interpreted as increasing operating pressure head lead to increase daily amount water then higher wetness degree and thus, higher activity of retting bacteria. Consequently, amount of water needed in the next day to compensate sun drying decreased; this lead to decrease retting days. Increasing operating time from 1.5 to $3 \mathrm{~h}$ increased total applied water at 5, 7.5 and $10 \mathrm{~m}$ operating pressure head, while at $12.5 \mathrm{~m}$ operating pressure head total applied water decreased; this may be due to wetness degree. Increasing operating pressure head from 5 to $7.5 \mathrm{~m}$ decreased total applied water by 6.0 and $5.7 \%$ for operating times 1.5 and $3 \mathrm{~h}$, respectively. Increasing operating pressure head from 7.5 to $10 \mathrm{~m}$ decreased total applied water by 2.3 and $14.3 \%$ for operating times 1.5 and $3 \mathrm{~h}$, respectively. Increasing operating pressure head from 10 to 12.5 m decreased total applied water by 3.5 and $22.2 \%$ for operating times 1.5 and $3 \mathrm{~h}$ respectively. At $5 \mathrm{~m}$ operating pressure head, sprinkler retting increased total applied water compared with traditional retting by 8.2 and $26.9 \%$ for operating times 1.5 and $3 \mathrm{~h}$, respectively. In contrast, at $12.5 \mathrm{~m}$ 
operating pressure head, sprinkler retting saved 4.0 and $20.3 \%$ of total applied water for operating times 1.5 and $3 \mathrm{~h}$, respectively compared with traditional retting. Sprinkler retting tacked a period ranged from 14 to 24 days while water (traditional) retting tacked 7 days. The lowest total applied water was $8.33 \mathrm{~m}^{3} /$ ton straw obtained at $\mathrm{T}_{2} \mathrm{P}_{4}$ treatment and the highest total applied water was $13.26 \mathrm{~m}^{3} /$ ton straw obtained at $\mathrm{T}_{2} \mathrm{P}_{1}$, while total applied water for water (traditional) retting was $10.45 \mathrm{~m}^{3} /$ ton straw. It should be noted that, in the case of using concrete basins with traditional retting, the amount of applied water would have increased where evaporation and leakage from the basin will be found.

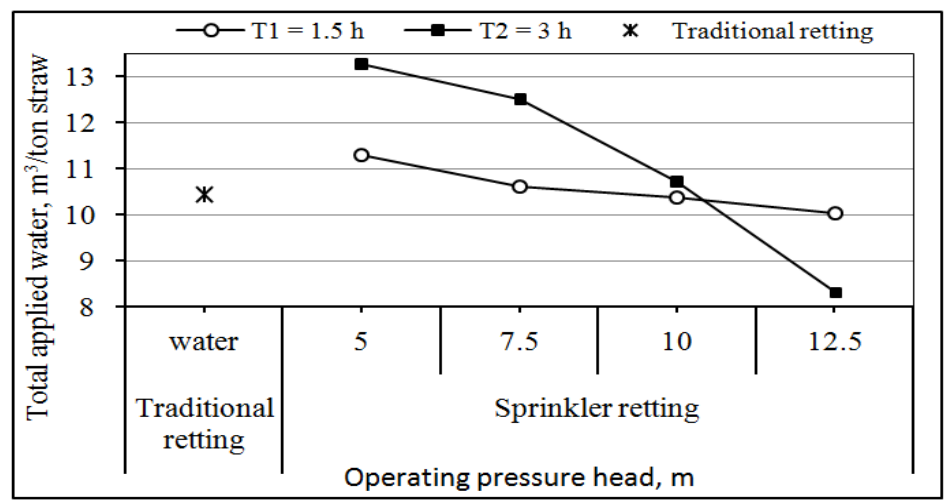

Fig.5. Effect of retting method and operating pressure head on total applied water.

\subsubsection{Fiber percentage:}

Fiber percentage in relation to retting method and operating pressure head are shown in Fig 6. The obtained results indicated that, fiber percentage was affected by retting method and sprinkler operating pressure head; water (traditional) retting led to increase fiber percentage compared with sprinkler retting. Under sprinkler retting, increasing operating pressure head from 5 to $12.5 \mathrm{~m}$ increased fiber percentage for two operating times. These results may be due to increase application uniformity by increasing operating pressure head. Increasing operating time from 1.5 to $3 \mathrm{~h}$ did not affect fiber percentage at 5 and $7.5 \mathrm{~m}$ operating pressure head, while fiber percentage increased at 10 and 12.5 $\mathrm{m}$ operating pressure head by increasing operation time. Increasing operating pressure head from 5 to $7.5 \mathrm{~m}$ increased fiber percentage by 0.8 
$\%$ for the two operating times, increasing operating pressure head from 7.5 to $10 \mathrm{~m}$ increased fiber percentage by 2.3 and $10 \%$ and increasing operating pressure head from 10 to $12.5 \mathrm{~m}$ increased fiber percentage by 12.7 and $8.4 \%$ for operating times 1.5 and $3 \mathrm{~h}$ respectively. Under $1.5 \mathrm{~h}$ operating time, sprinkler retting decreased fiber percentage compared with traditional retting by $20.5,20,18.1$ and $7.7 \%$ at operating pressure heads $5,7.5,10$ and $12.5 \mathrm{~m}$, respectively. Under $3 \mathrm{~h}$ operating time, sprinkler retting decreased fiber percentage compared with traditional retting by $21.1,20.5,12.6$ and $5.3 \%$ at $5,7.5,10$ and $12.5 \mathrm{~m}$ operating pressure heads, respectively. The lowest fiber percentage under sprinkler retting was $12.9 \%$ obtained at $\mathrm{T}_{2} \mathrm{P}_{1}$ treatment and the highest one was $15.5 \%$ obtained at $\mathrm{T}_{2} \mathrm{P}_{4}$ treatment, while water (traditional) retting produced $16.36 \%$ fiber percentage.

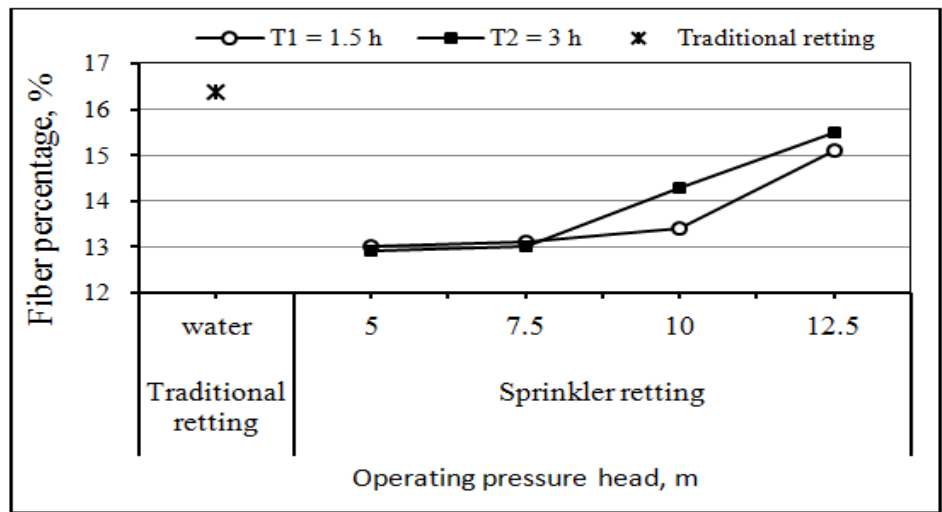

Fig. 6. Effect of retting method and operating pressure head on fiber percentage.

\subsubsection{Fiber fineness and fiber length:}

Fiber fineness and fiber length in relation to retting method and operating pressure head are shown in table 2 . The obtained results indicated that fiber fineness and fiber length were affected by retting method and sprinkler operating pressure head, where sprinkler retting enhanced fiber fineness comparing with traditional retting. Under sprinkler retting, increasing operating time enhanced fiber fineness and fiber length at different operating pressure head, while increasing operating pressure head reduced fiber fineness and fiber length this result may be due to 
decrease total applied water by increasing operating pressure head. The highest fiber fineness value were 273 obtained at $\mathrm{T}_{2} \mathrm{P}_{2}$ treatment which increased by $30 \%$ compared with traditional retting and the lowest fiber fineness value were 262 obtained at $\mathrm{T}_{1} \mathrm{P}_{3}$ treatment which increased by $24.8 \%$ when compared with water (traditional) retting; fiber fineness for traditional retting was 210 .

The highest fiber length value under sprinkler retting were $84.9 \mathrm{~cm}$ obtained at $\mathrm{T}_{2} \mathrm{P}_{1}$ treatment which was less by $3 \%$ than traditional retting and the lowest fiber length value were $82.7 \mathrm{~cm}$ obtained at $\mathrm{T}_{1} \mathrm{P}_{4}$ treatment which was less by $5.5 \%$ than traditional retting; where fiber length for traditional retting was $87.5 \mathrm{~cm}$.

Table 2: Effect of retting method and operating pressure head on fiber fineness and fiber length.

\begin{tabular}{|c|c|c|c|c|c|c|}
\hline \multirow{2}{*}{$\begin{array}{l}\text { Fiber } \\
\text { quality }\end{array}$} & \multirow{2}{*}{$\begin{array}{l}\text { Operating } \\
\text { time, } \mathrm{h}\end{array}$} & \multicolumn{4}{|c|}{ Sprinkler retting } & \multirow{2}{*}{$\begin{array}{c}\text { Water } \\
\text { (traditional) } \\
\text { retting }\end{array}$} \\
\hline & & $\mathrm{P} 1=5 \mathrm{~m}$ & $\mathrm{P} 2=7.5 \mathrm{~m}$ & $\mathrm{P} 3=10 \mathrm{~m}$ & $\mathrm{P} 4=12.5 \mathrm{~m}$ & \\
\hline \multirow{2}{*}{$\begin{array}{c}\text { Fiber } \\
\text { fineness }\end{array}$} & $\mathrm{T}_{1}=1.5$ & 269 & 270 & 262 & 264 & \multirow{2}{*}{210} \\
\hline & $\mathrm{T}_{2}=3$ & 271 & 273 & 267 & 268 & \\
\hline \multirow{2}{*}{$\begin{array}{c}\text { fiber } \\
\text { length, } \\
\mathrm{cm}\end{array}$} & $\mathrm{T}_{1}=1.5$ & 84.2 & 83.2 & 82.9 & 82.7 & \multirow{2}{*}{87.5} \\
\hline & $\mathrm{T}_{2}=3$ & 84.9 & 84.8 & 83.2 & 83.1 & \\
\hline
\end{tabular}

\subsubsection{Water productivity:}

Water productivity in relation to retting method and operating pressure head are shown in Fig 7. The obtained results indicated that water productivity was affected by retting method and sprinkler operating pressure head, where sprinkler retting led to increase fiber percentage compared with traditional/water retting. Under sprinkler retting, increasing operating pressure head increased water productivity for the two operating times, where total applied water decreased and fiber percentage decreased. Increasing operating time from 1.5 to $3 \mathrm{~h}$ decreased water productivity at 5 and $7.5 \mathrm{~m}$ operating pressure heads, while at 10 and $12.5 \mathrm{~m}$ operating pressure heads water productivity increased. Increasing operating pressure head from 5 to $7.5 \mathrm{~m}$ increased water productivity by 7 and $7.2 \%$ for the two operating times 1.5 and 3 $\mathrm{h}$, respectively. Increasing operating pressure head from 7.5 to $10 \mathrm{~m}$ increased water productivity by 4.9 and $28.8 \%$ for the two operating 
times 1.5 and $3 \mathrm{~h}$, respectively. Increasing operating pressure head from 10 to $12.5 \mathrm{~m}$ increased fiber percentage by 17 and $38.8 \%$ for the two operating times 1.5 and $3 \mathrm{~h}$, respectively. Under $1.5 \mathrm{~h}$ operating time, sprinkler retting decreased water productivity compared with traditional retting by $26.8,21.7,17.8$ and $3.8 \%$ at different operating pressure heads, respectively. Under $3 \mathrm{~h}$ operating time, sprinkler retting decreased water productivity compared with traditional retting by $38.2,33.8$ and $14.6 \%$ at $5,7.5$ and $10 \mathrm{~m}$ operating pressure heads, respectively and increased by $18.5 \%$ at $12.5 \mathrm{~m}$ operating pressure head. The lowest water productivity value under sprinkler retting was $9.7 \mathrm{~kg} / \mathrm{m}^{3}$ obtained at $\mathrm{T}_{2} \mathrm{P}_{1}$ treatment and the highest one was $18.6 \mathrm{~kg} / \mathrm{m}^{3}$ obtained at $\mathrm{T}_{2} \mathrm{P}_{4}$, while water productivity for water (traditional) retting was $15.7 \mathrm{~kg} / \mathrm{m}^{3}$.

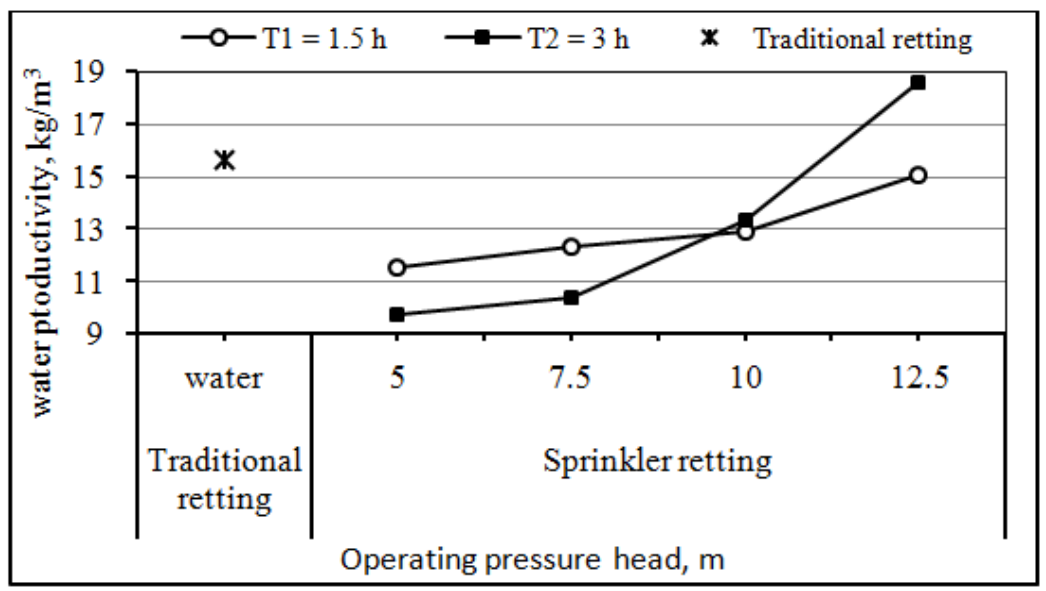

Fig. 7. Effect of retting method, operating time and operating pressure head on water productivity.

\section{CONCLUSION}

Sprinkler retting can be an alternative retting method for water retting method where it has many advantages, including saving water, less labor, no odor and reduced cost and without occupying area like retting basin in traditional method. Further research is needed to minimize retting period and enhance fiber characters (percentage, fineness and quality).

\section{REFERENCES}

Evans, J. D.; D. E. Akin; W. H. Morrison and D. S. Himmelsbach (2002). Modifying Dew-Retted Flax Fibers by Means of Airatomized Enzyme Treatment. Textile Res. J. 72, 579-585. 
Hassan, M. H.; M. E. Kiwan; A. El-Amin and M. S. Abuarab (2007). Hydraulic characteristics and water distribution patterns of microsprinkler irrigation systems. Misr J. Ag. Eng., 24(4): 849885 .

Henriksson, G.; K. E. L. Eriksson; L. Kimmel and D. E. Akin (1998). Chemical/Physical Retting of Flax Using Detergent and Oxalic Acid at High pH. Textile Res. J. 68: 942-947.

James, L.G. (1988). Principles of farm irrigation system design. John Willey/Sons (ed.), New York: 543.

Konczewicz, W. and J. Wojtysiak (2015). The effect of physical factors on the process of physical-mechanical degumming of flax fibers. Textile Res. J. 85 (4): 391-403

Konczewicz, W.; M. Zimniewska and M. A. Valera (2017). The selection of a retting method for the extraction of bast fibers as response to challenges in composite reinforcement. Textile Res. J. $0(00) 1-16$.

Kozlowski, R.; W. Konczewicz and J. Wojtysiak (2006). Device for processing fibrous raw materials and the method of fibrous plants processing. Institute of Natural Fibers \&Medicinal Plants. Poland. Patent application EP 2242876 B1, Date of filing: 23 November. European patent.

Mehawed, H. S.; A. M. El-Shazly and Y. E. Arafa (2013). Hydraulic performance assessment of sprinkler types for improving on- arm irrigation efficiencies. Third International Conference for Agricultural \& Bio-engineering. Egypt. J. Ag. Res., 91 (2A):367379.

Playan, E.; N. Zapata; J. M. Faci; D. Tolosa; J. L. Lacueva and J. Pelegrin (2006). Assessing sprinkler irrigation uniformity using a ballistic simulation model. Agricultural Water Management, 84 (12): $89-100$.

Radwan, S. R. H. and A. Momtaz (1966). The technological properties of flax fibers and the methods of estimating them. El-Falaha J. 46(5): 466-476 (In Arabic). 
Sanchez, I; N. Zapata and J. M. Faci (2010). Combined effect of technical, meteorological and agronomical factors on solid set sprinkler irrigation: I. Irrigation performance and soil water recharge in alfalfa and maize. Agricultural Water Management, 97 (10): 1571-1581.

Van Sumere, C. F. (1992). Retting of Flax with Special Reference to Enzyme-retting, in "The Biology and Processing of Flax," H. S. S. Sharma and C. F. Van Sumere, Eds., M Publications, Belfast, Northern Ireland, pp. 157.

Zhu, X.; S. Yuan; J. Jiang; J. Liu and X. Liu (2015).Comparison of fluidic and impact sprinklers based on hydraulic performance. Irrig Sci. 33: 367-374.

\section{الملذص العربي \\ تعطين الكتان باستخدام نظام الرش

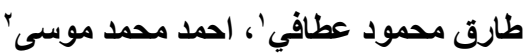

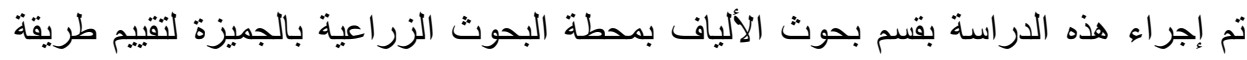

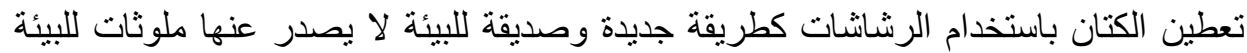

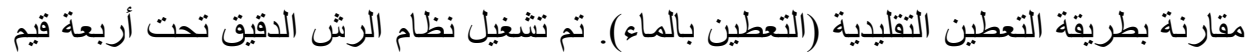

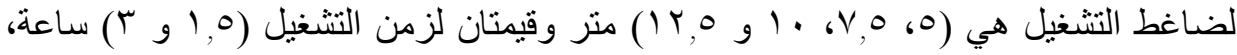

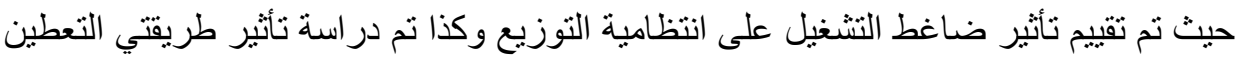

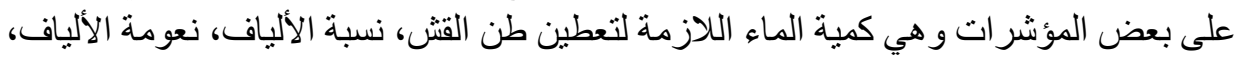
طول الألياف و إنتاجية الماء.

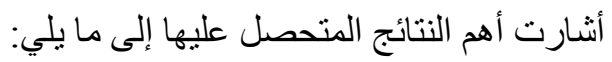

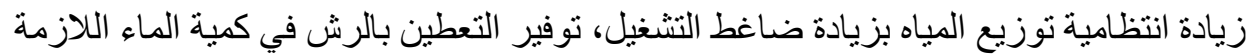

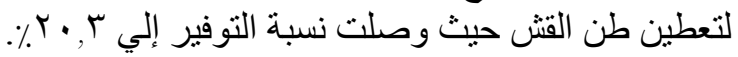
التعطين التقليدي أعطى نسبة ألياف ع,7 1\% بينما أعلى نسبة ألياف مع التعطين بالرش كانت الته

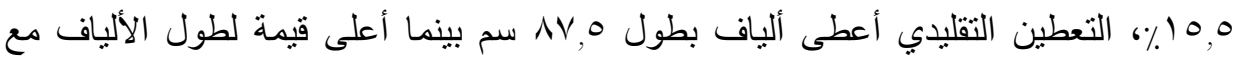

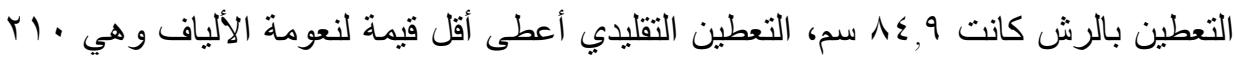

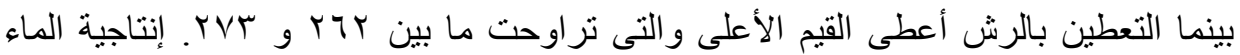

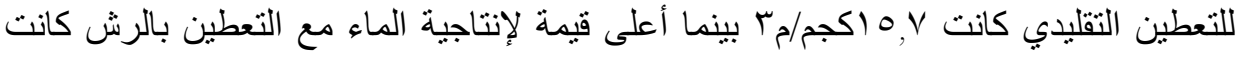

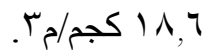

'باحثـ معهـ بحوث الهندسة الزراعية ــ مركز البحوث الزراعية ـ مصر.

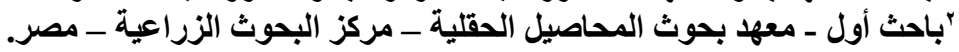

